UDC 330.117

DOI: $10.24044 / \mathrm{sph} .2017 .4 .38$

\title{
THE RELATIONSHIP BETWEEN CONSULTING AND STRATEGIC DECISION-MAKING IN THE SMALL AND MEDIUM SIZED FAMILY FIRMS - THE CASE IN VIETNAM
}

H. D. Nguyen

N. Th. Nguyen

T. B. Nguyen

\author{
PhD, Lecturer, ORCID 0000-0002-5858-7946, \\ e-mail: huudan78@gmail.com, \\ masters' degree in Political Economy, \\ PhD student,
}

ORCID 0000-0002-1361-0401, e-mail: thangnguyenthangctttth@gmail.com, Diep, Masters' degree in Political Economy, PhD student, ORCID 0000-0003-3562-924X,

e-mail: bachdiep72@gmail.com,

Political School of Thanh Hoa Province,

Than Hoa, Vietnam

\begin{abstract}
The article analyzes the importance and current status of small and medium-sized family businesses. The business consultant role in strategic decision-making affects the survival and development of small and medium-sized family enterprises. The paper also analyzes the status of hiring consultants in small and mediumsized family enterprises in Vietnam, thus pointing out the issues that need to be studied, as well as the contribution of research results to the enhancement of business survival.

Keywords: consulting; strategic decision-making; small and medium-sized family firm; Vietnam communist party; socio-economic development.
\end{abstract}

One of the major challenges for $\mathrm{Vi}$ etnam's political system is implementing the Resolution to achieve the goals. In particular, the goal of development and support of 2 million family businesses by 2030 is one of the most important contents of the Resolution. Establishing and registering a business is the initial step. However, it is very difficult for businesses to operate smoothly, flexibly, effectively and survive over time. Therefore, finding consultants or consulting firms to support running business is one of the crucial solutions to help family companies survive and develop effectively.

In the framework of the study, this research mentions the importance of the family businesses and the business consulting role, current status of hiring business consultants in small and medium-sized family companies in Vietnam. The study points out the issues that need to be studied as well as its contribution to the performance of small and medium-sized family businesses.
The importance and current status of small and medium sized family firms (SMFFs)

The survival of the family businesses is critical to the sustainability of economies. In fact, most countries in the economic development process have realized the importance of the small and medium sized family companies for the economic growth. In the United Kingdom, according to the DTI Annual Survey of Small Business Data [5], the family businesses accounted for 68 percent of the total population of small and medium sized enterprises employers. Family business accounted for 65 percent of private sector enterprises, 41.9 percent of private sector employment, and 38.2 percent of private sector turnover [7; 9].

However, results from a survey of family enterprises in Vietnam by Chamber of Commerce and Industry of Vietnam [17] has estimated that the Vietnamese family business sector today is almost nothing, and should be 
developed from the very beginning. This means after 30 years of economic development, the background activity of the family business sector is almost zero. They are still being operated spontaneously, and follow the family-style management, which is operative fragmentation, lack of operational strategies, as well as weakness in capability of strategic decision-making, so family enterprises silently drift with a tendency to "self-born, selfdefeat" [15].

The figure given in the results is really surprising. The number of family enterprises is increasing, but the size of the business is shrinking. Particularly, regarding the capital size; in cash flow in 2012, the capital size of family companies has increased slightly, but regarding inflation, the size of the business has reduced in a half compared to the year 2002.

In the eyes of policy makers SMFFs in Vietnam are third class citizens. They are behind the state-owned enterprises and FDI enterprises. Meanwhile, SMFFs account for $96 \%$ of all registered enterprises in Vietnam and generated $40 \%$ of gross domestic product (GDP) [16]. For over 10 years, SMFFs have become an important part of Vietnamese economy. Hundreds of thousands of SMFFs have created jobs for more than half of the non-agricultural labor in the country. However, they are still seen as the vulnerable people sitting bottom of the economy.

Specifically, in June 2011, inflation increased by nearly $21 \%$ comparing with the same period in 2010, in which prices of food increased by $30 \%$ and travel expenses increased by $20 \%$. In July 2011, Vietnam's inflation increased to $22.16 \%$, the highest level in 17 countries in Asia. The trade deficit increased to 200 million USD. SMFFs are impacted the most severely by the inflation, so interest rate credit increased to $20 \%$. Therefore, businesses cannot make a profit in production [8].

SMFFs are stuck. They cannot grow in size due to the lack of capital and technology [14]. Only one third of SMFFs can reach the bank credit sources while 3/4 of all SMFFs need credit loans [11]. Up to one third of the number of workers in SMFFs lost their jobs in 2011 , and $30 \%$ of SMFFs stopped operating since late 2010 , and the situation continues to occur.

Furthermore, private business sector is one of the driving forces of Vietnamese economic growth today (including three main sectors: state enterprises, FDI enterprises, and private enterprises). In fact, the stateowned enterprises and FDI enterprises are interesting to the state due to tax, fees, land, etc. while the private business community has not received the support and benefits from the state on those issues. They seem to be abandoned by the government and must attempt to cope with the difficulties [10].

In addition, the confidence of enterprises is also being declined strongly. Specifically, in 2013 the survey results showed that fewer than $30 \%$ of the number of businesses declared that they would continue to invest and expand their operations. Up to now, this ratio has dropped faster, which shows that the businesses' confidence declines dramatically [16; 10]. These may come from some reasons.

Firstly, the most difficult elements of the family business sector is the law, finance and management. In fact, many businesses complain about the law confusion and the overlap between the legal documents as well as the difficulties in enforcement. This has been struggling for businesses. For example, a kind of activity is maybe encouraged by the law, but according to other regulations, it is not. This reason makes enterprises fall into the vague status of legal corridor, and put them into the situation that their business is still going on, but they do not know whether wrong or right with laws [10].

Secondly, the government's business current support policy is unrealistic. Therefore, family businesses cannot put their activities into practice. For example, to support the supporting industries, a number of policies have been enacted. However, these policies are only general and non-specific. Therefore, the implementation of these policies is impeded. Businesses which want to engage in 
business in these areas are always worried about risks because policies on land, credit, taxes and fees are not well implemented [17].

Thirdly, concerning the problem of affiliate business Vietnamese state enterprises and foreign-invested firms tend to build a standalone and self-contained operation. The state enterprises set up the subsidiaries - the backyard companies. Thus, they can mobilize resources from these units if they need. Therefore, they do not need to connect with other businesses, especially SMFFs [17].

FDI enterprises in Vietnam are expected to have spillover effects on the domestic family enterprises in order to turn domestic enterprises into satellites around them. However, until now, this idea nearly cannot be implemented because the input resources for FDI enterprises still belong to areas of their businesses, not in Vietnam (70-80 \% input material in the other countries). There are only few Vietnamese family businesses joining these operation chains. For example, the Samsung Company has invested to produce cellphone and electronic devices in Vietnam; the export scale of this company is up to $\$ 23$ billion, but only about five domestic enterprises have been engaged in providing package, labels and the technology field is almost zero.

Although family firms stand between two large areas (State Enterprises and FDI companies) and account a large number, they are still faint. They struggle to operate because they can use only their own resources and cannot cooperate with other companies. Therefore, the investment capital into private sector in recent years has significantly reduced. Family firms now are unwilling to invest. [17] Specifically, at the end of 2013, the contribution of family firms to the growth of Vietnamese economy has reduced to approximately $38 \%$ of GDP comparing to 2006, family firms accounted for $39 \%$ of GDP [3].

\section{Consulting - an important factor in business operation}

Consultants have an important role in the businesses. According to ordinary dictionary it is "advice is the comments on the issues being questioned, but has no power to decide". From this concept, we have advisory councils, advisory agencies, consultants, consulting firms, consulting functions and so on.

The development of society leads to the expansion of consulting services. Consultants and the professional consulting services are not only giving the "comments", but also supporting important contents such as researching and warning hazard, researching and offering opinions on the observance of the law provisions, researching investment plans and choosing an optimal plan for business, investment and so on. Following the momentum of economic development, consulting has become an independent field and contributed to the growth of state economy.

According to the ordinary dictionary, business is an organized production, trade and providing services aimed at making profit. In Vietnam, according to the Laws of Enterprises (2005), business is the one, several or all stages of the investment process, from manufacturing to sale products or providing services to meet the customer demands on the market field which aims to profit.

Economic history of developed countries shows that in the market economy the consultants have and will become important factors in the business of enterprises and entrepreneurs. The importance of consulting is determined by the following reasons.

First, the business is defined by the owner (or owner's representative) - also known as the business owner. In fact, small or large enterprises cover a wide range of industries, but there are no business owners with the necessary knowledge in all areas of business. Therefore, the owner of the family company has to find the consultant or consulting firm to fill "knowledge gaps".

Secondly, to keep the business develop sustainably, the business scale must be great- 
er than the previous cycle, and therefore, the business scope must also be broadened or business has to implement the new investment projects. Hence, the need about knowledge to serve the new business operations such as information about market, product, technology, project management, the law in various countries and regions always occur and require timely resolution. Very few entrepreneurs can meet those requirements, so seeking and using the consulting services is an objective indispensability.

Thirdly, in any environment the risks always follow the business. Minimizing the damages that can occur from the threats is the best method. This means that businesses must identify risks, assess the possibility and take corrective action. However, to precisely identify the risks requires the owner must have an objective view, understand the business situation. However, business owners are insiders, with a lot of work to do and so many things to worry about. Thus, it is difficult for them to look objectively and comprehensively in all cases. In contrast, consultants are able to meet these requirements.

Fourthly, in terms of professionalism and efficiency, with a lot of work from different fields, business owners can't implement new processes on a highly professional level. In contrast, consultants or consulting firms specialize in each area and process in specific cases. Therefore, with the similar tasks, the consultant will handle faster, more professional and thus will ensure greater efficiency.

The above reasons are the basic and most important to confirm that consultants are important factor in running business of all enterprises. With the growth of the market economy, the role of consultants for business is even higher. In developed countries, depending on the size of the firm, business owners often hire one or more consultants to meet various demands of the business. This is one of the important conditions to ensure the sustainability of the business. However, with the emphasis on the importance of consulting, it is critical to remember that consultants are not allowed to make decisions for business owners. Therefore, the effectiveness of the consultant relies primarily on the entrepreneur's final decision. Therefore, the managerial capacity and level of socioeconomic awareness of business owners remain important conditions for the existence and development of enterprises.

The status of consulting service in SMFFs

Vietnam has been deeply involved in the world economy, especially after joining the World Trade Organization (WTO). The priorities for the domestic businesses are getting shrinking and losing. Therefore, it is required that all to use professional consulting services to search ideas, valuable information serving various business field.

WTO accession brings many opportunities for businesses in Vietnam, but also brings lots of challenges and fierce competition in the international business market and even in the domestic market. Hence, the enterprises need to strengthen and enhance all aspects relating to business and development such as building the business strategy, human resource development, technical application, production technology to improve labor efficiency reduce expenses and so on, so that they can survive and thrive on the global business market. It is essential to seek help from the business consultants to achieve these goals. However, business owners also need to be proactive and flexible in approaching and adapting the new business environment.

According to economic experts, the family firms using the counseling services tend to increase, but it is not really popular [10]. This can explain that Vietnamese enterprises are still not fully aware of the consulting service importance. On the other hand, the financial enterprise resources especially the SME's are limited, so the enterprises hesitate to use the consulting services and do not want to pay a bundle of money to hire a consultant.

For example, currently, price and design consultation for a packaging design is from 150 to 250 USD. For foreign companies, this 
is cheap, while for Vietnamese enterprise, it is relatively high. More than 1,000 regular customers of the Hy Chi Fine Art Company in Ho Chi Minh City include up to $60 \%$ of foreign companies and the rest of the largerst enterprises such as Trung Nguyen Company, Thai Tuan Company, and Kinh Do Company use the above consultation. Likewise, the businesses which wants to bring their product into the market have to pay Solar Consulting Company $10 \%$ profit or 3-5\% of total revenue during at least a year. Furthermore, to implement an ISO standard, companies must spend at least 3500-5000 USD. The main costs for consulting services is relatively high, so SMFFs are often "shock" and hesitate to decide to hire a consulting service.

Besides, when businesses are interested in consulting services, they are confused and do not know about the point to start, and how to find a suitable consultant. In fact, due to the necessity of expanding the market, a company contracts directly with a consultancy unit to develop the HACCP standards (standards for food safety). After collaboration, the company realizes that its partners were continually changing the counselors. Through exploring the related information, this company realizes that they work with a partner without expertise and no personnel; and the "experts" who give advice to the company are still students at universities. Thus, the quality of consultative services is not convincing.

As a consequence, the percentage of enterprises using advisory services is not high. The scale of consulting activities in Vietnam can be described as following: Ho Chi Minh City scale is the highest, accounting for $59.8 \%$; Hanoi Capital, accounts for $32.9 \%$; Da Nang City, accounts for $4.9 \%$; Can Tho City, accounts for $2.4 \%$. In Vietnam, the age of consulting firms is quite young, for instance, the 2-3-year-old consulting firms accounting for $41.2 \%$; the less 2-year-old consulting firms accounting for $27.4 \%$; the over-10-year-old consulting firms accounting for only $8.2 \%$ [17]. In particular, the con- struction consultancy takes the highest proportion of $30 \%$; HR consulting, legal consulting, management consulting, accounting and financial consulting, account for only $10-15 \%$ for each field [17].

\section{Studies in need}

Some researchers of decision-making process recommend that the managers in the various organizations or even within the same organization may consider internal or external problems quite differently [4]. There are no studies of long-term or short-term efficiency of using consulting services in the family businesses [2]. The research of the intervention of firm advisors to the process of strategic decision-making is ignored [12]. Moreover, the research of the family business consultation reveals that although they have received considerable attention, but the research of the effectiveness of the advisory process intervening in the strategic decisionmaking is limited [12] while the strategic decision-making is a key element of management in the core conceptions of organizations [1]. The study purpose points out the importance of using consulting services in SMFFs and it also gives some recommendations to the future research which are the following:

First, the gaps existing in the literature of consulting procedure where the perspectives of the researchers and practitioners are not integrated to understand the intervention and long-term or short-term efficacy of advising process in SMFFs, especially the way to intervene the process of strategic decisionmaking in SMFFs.

Second, the usage of consulting is a common phenomenon in enterprises of developed countries, especially in large scale business, but it is not very widespread in developing countries, and especially in small and medium scale businesses. The future studies need to investigate this kind of service in the developing countries, particularly in SMFFs.

Third, the study results not only open a new approach about using consulting ser- 
vices in developing countries especially in Vietnam but they also explain the counseling process. Moreover, they provide information to researchers, practitioners, economists, business owners, educators, social scientists in order to better understand the needs of using consultant service in SMFFs.

Finally, the future study should use SMFF samples of various sources to conduct research of relationship between consultants and the strategic decision-making.

\section{Bibliography}

1. Astley, W. G., and Van de Ven, A. H. (1983). Central perspectives and debates in organization theory. Administrative Science Quarterly. 28. 245-273.

2. Astrachan, J. H., and McMillan, K. S. (2006). United States. In F. W. Kaslow (Ed.), Handbook of family business and family business consultation: A global perspective (pp. 347-363). Binghamton, NY: International Business Press.

3. Cuong Tran Tien, Le Xuan Sang, Nguyen Kim Anh, Tulusambunan, (2009). Development of small and medium enterprises in Vietnam and Indonesia.

4. Dean, J.W. Jr. And Sharfman, M.P. (1993). Procedural rationality in the strategic decisionmaking process. Journal of Management Studies. 30, 587-611.

5. DTI, (2006). The Annual Survey of Small Businesses' Opinions 2006/07 (ASBS 2006/07), Summary report of findings among UK SME em- ployers, URN 07/389, IFF Research Ltd, February 2008.

6. Dutton, J.E. (1993). Interpretations on automatic: a different view of strategic issue diagnosis. Journal of Management Studies. 30, 339-357.

7. GEM report, (2006). Global Entrepreneurship Monitor 2006 Financing Report.

8. GSO (2011) "Tổng cục thống kê" General Statistics Office of Vietnam

9. IFB report, (2008). The UK Family Business Sector: An Institute for Family Business report by Capital Economics.

10. Lan Pham Chi, (2014). A Survey of Vietnam SMEs

11. MPI (2011) "Bộ kế hoạch và đầu tư Việt Nam" Viet Nam Ministry of Planning and Investment

12. Papadakis, V.M., Lioukas, S. and Chambers, D. (1998). Strategic decision-making processes: the role of management and context. Strategic Management Journal. 19, 115-147.

13. Rajagopalan, N., A.M.A. Rasheed and D.K Datta, Strategic Decision Processes: Critical Review and Future Directions, Journal of Management, (1993), pp. 349-384.

14. SMESC, (2011). "Trung tâm hỗ trợ doanh nghiệp vừa và nhỏ Việt Nam 2011", Vietnam SME Support Center.

15. VCCI, (2012). Vietnam Chamber of Commercial and Industrial

16. VCCI, (2013). Vietnam Chamber of Commercial and Industrial

17. VCCI, (2014). Vietnam Chamber of Commercial and Industrial

(C) Nguyen H. D., Nguyen N. Th., Nguyen T. B., 2017. 